\title{
KUALITAS FISIK UDARA DI TERMINAL BUS BULUPITU PURWOKERTO KABUPATEN BANYUMAS TAHUN 2015
}

\author{
Anugrah Putradana ${ }^{1)}$, Tri Cahyono ${ }^{2)}$ \\ Jurusan Kesehatan Lingkungan, Politeknik Kesehatan Kemenkes Semarang, \\ Jl. Raya Baturaden KM 12 Purwokerto, Indonesia
}

\begin{abstract}
Abstrak
Terminal Bus Bulupitu Purwokerto Kabupaten Banyumas merupakan tempat sarana transportasi darat tipe A dengan jam operasi 24 jam. Pengunjung 50\% merasa kebisingan, $15 \%$ cepat pegal, $20 \%$ kepanasan, $15 \%$ merasa pening. Mengukur kualitas fisik udara berupa intensitas suara, intensitas pencahayaan, suhu dan kelembaban. Metode penelitian ini adalah deskriptif. Penelitian ini dilakukan di ruang pengelola terminal, ruang tunggu pengunjung dan ruang pedagang. Hasil pengukuran intensitas suara pada hari pertama $65,48 d B(A)-73,76 d B(A)$ dengan rata-rata $69,72 d B(A)$, hari kedua $64,18 d B(A)-71,99 d B(A)$ dengan rata-rata $67,42 d B(A)$, dan hari ketiga55,24 $d B(A)-71,39 d B(A)$ dengan rata-rata 63,48 $d B(A)$. Hasil pengukuran intensitas cahaya hari pertama 16 Lux - 715 Lux dengan rata-rata 178,33 Lux, harikedua15 Lux-235 Luxdengan rata-rata 87,33 Lux, dan hari ketiga 16 Lux-1035Lux dengan rata-rata $245,66 \mathrm{Lux}$. Hasil pengukuran suhu hari pertama $28^{\circ} \mathrm{C}-30^{\circ} \mathrm{C}$ rata-rata $28,6^{\circ} \mathrm{C}$, hari kedua $30^{\circ} \mathrm{C}-32^{\circ} \mathrm{C}$ rata-rata $31,16^{\circ} \mathrm{C}$, hari ketiga $27^{\circ} \mathrm{C}-30^{\circ} \mathrm{C}$ dengan rata-rata $28,5^{\circ} \mathrm{C}$. Hasil pengukuran kelembaban hari pertama 52\%-70\% dengan rata-rata 60,5\%, hari kedua $48 \%-57 \%$ dengan rata-rata $51,33 \%$ dan hari ketiga 45\%-58\% dengan rata-rata 52,83\%. Simpulan empat pengukuran kualitas fisik udara memenuhi syarat. Saran dapat dilakukan membuat celah di atap dengan kaca agar cahaya alami masuk.
\end{abstract}

Kata Kunci : Kualitas Fisik Udara, Terminal, Kesehatan Lingkungan

\begin{abstract}
Bulupitu Purwokerto bus station, Banyumas Regency is a type A land transportation that operate 24 hours a day. Passengers reached 5.000 per day. The problem that occurs in 50\% of visitors was noise, $15 \%$ felt stiff quickly, $20 \%$ heating problem, $15 \%$ dizziness. Physical air quality i.e. noise intensity, illumination intensity, temperature and humidity. The research method used was descriptive design. The research was conducted in bus station managemen office, visitor reception area and merchant area. The noise intensity on the first day was $65.48 \mathrm{~dB}(\mathrm{~A})-73.76 \mathrm{~dB}(\mathrm{~A})$ average was $69.72 \mathrm{~dB}(\mathrm{~A})$, second day was $64.18 \mathrm{~dB}(\mathrm{~A})-71.99 \mathrm{~dB}(\mathrm{~A})$ average was $67.42 \mathrm{~dB}(\mathrm{~A})$, third day was $55.24 \mathrm{~dB}(\mathrm{~A})-71.39 \mathrm{~dB}$ (A) average was $63.48 \mathrm{~dB}$ (A). The illumination on the first day was $16 \mathrm{Lux}-715 \mathrm{Lux}$ average was of 178.33 Lux, second day was 15 Lux - 235 Lux the average was 87.33 Lux, and third day $16-1035$ Lux average was $245.66 \mathrm{Lux}$. The temperature on first day was $28^{\circ} \mathrm{C}-30^{\circ} \mathrm{C}$ the average was of $28.6^{\circ} \mathrm{C}$, the second day was $30^{\circ} \mathrm{C}-32^{\circ} \mathrm{C}$ the average was $31.16^{\circ} \mathrm{C}$, the third day was $27^{\circ} \mathrm{C}-30^{\circ} \mathrm{C}$ average was $28.5^{\circ} \mathrm{C}$. The Humidity on first day was $52 \%-70 \%$ average was $60.5 \%$, second day was $48 \%-57 \%$ average was $51.33 \%$ and the third day was $45 \%-58 \%$ average was $52.83 \%$. The conclusions drawn for four measurementsair physical qualitywas qualify the regulation applied. Proposed suggestion was expected to slit the roof with glass tile so that natural light can extent.
\end{abstract}

Keyword : Air Physical Quality. Station. Environmental Health

\section{PENDAhuluan}

Kesehatan Lingkungan adalah upaya pencegahan penyakit dan/atau gangguan kesehatan dari faktor risiko lingkungan untuk mewujudkan kualitas lingkungan yang sehat baik dari aspek fisik, kimia, biologi, maupun sosial (PP RI No.66 tahun 2014). Kesehatan ditunjukan untuk mewujudkan lingkungan yang sehat, baik fisik, kimia, biologi maupun sosial yang memungkinkan setiap orang mencapai derajat kesehatan yang setingi-tingginya, lingkungan yang sehat mencakup lingkungan permukiman, tempat

1) E-mail : anugrahputradana@yahoo.com

2) E-mail: statistikan@yahoo.com kerja, tempat rekreasi, serta tempat dan fasilitas umum (UU No 36 Tahun 2009).

Tujuan penyehatan sarana dan bangunan umum adalah terselenggaranya upaya untuk meningkatkan pengendalian faktor risiko penyakit dan kecelakan pada sarana dan bangunan, tempat umum antara lain hotel, penginapan, pasar, bioskop, tempat rekreasi, kolam renang, terminal, bandar udara, pelabuhan laut, dan pusat perbelanjaan (Kepmenkes RI No 288/Menkes/SK/III/2003).

Menurut Peraturan Pemerintah Repulik Indonesia No 74 Tahun 2014, terminaladalah pangkalan 
bermotor umum yang digunakan untuk mengatur kedatangan dan keberangkatan, menaikkan dan menurunkan orang dan/atau barang, serta perpindahan moda angkutan. Terminal merupakan tempat yang paling cocok untuk menyebarnya segala penyakit yang dibawa oleh orang-orang yang keluar masuk disana maupun yang berasal dari terminal itu sendiri. Terutama yang penyebarannya melalui media udara, air, makanan, minuman maupun kontak manusia satu dengan yang lainnya.

Hasil survei 10 penumpang yang terdapat di ruang tunggu penumpang terminal Purwokerto tahun 2014, bahwa $50 \%$ pengunjung gelisah akibat kebisingan yang ditimbulkan dari aktifitas terminal, $15 \%$ pengunjung mata cepat pegal karena penerangan mulai redup, $20 \%$ pengunjung sangat panas karena cuaca yang berubah-ubah ditambah dengan asap yang dikeluarkan oleh bus yang sedang parkir, 15\% pengunjung sering merasa pening akibat aktifitas didalam terminal. Peneliti merumuskan masalah penelitian "Berapakah kualitas fisik udara di Terminal Bus Bulupitu Purwokerto Kabupaten Banyumas Tahun 2015?"

Tujuan penelitian adalah mengetahui kondisi kualitas fisik udara di Terminal Bus Bulupitu Purwokerto Kabupaten Banyumas Tahun 2015

\section{BAHAN DAN CARA}

Jenis penelitian ini adalah deskriptif. Penelitian mengukur kualitas fisik udara di Terminal Bus Bulupitu Purwokerto Kabupaten Banyumas. Subyek penelitian adalah intensitas suara, intensitas cahaya, suhu, dan kelembaban. Sampel diambil dari ruang pengelola terminal, ruang tunggu penumpang, dan ruang pedagang. Cara pengukuran menggunakan sonud level meter, luxmeter, dan thermohygrometer.

\section{III.HASIL DAN PEMBAHASAN}

\section{Hasil}

Terminal Bus Bulupitu Purwokerto Kabupaten Banyumas sebagai tempat umum yang sering dilakukan untuk berbagai aktifitas dan keluar masuknya bus dan kendaraan pribadi lainnya.

Hasil pemeriksaan kualitas fisik udara di Terminal Bus Bulupitu Purwokerto Kabupaten Banyumas hasil rata-rata intensitas suara memenuhi syarat, intensitas cahaya memenuhi syarat, suhu memenuhi syarat, kelembaban memenuhi syarat.

\section{Pembahasan}

Menurut Suma'mur (2009.h.115) suara adalah suara yang didengar sebagai rangsangan pada sel saraf pendengar dalam telinga oleh gelombang longitudinal yang ditimbulkan getaran dari sumber bunyi.

Intensitas suara dapat terjadi bila gelombang bunyi yang dihasilkan merambat pada angin, atau bisa dipantulkan ke benda-benda yang dekat pada sumber bunyi. Pengukuran intensitas suara dengan rata-rata pada hari pertama yaitu $69,72 \mathrm{~dB}(\mathrm{~A})$ dengan hasil tertinggi 73,76 $\mathrm{dB}(\mathrm{A})$ dan hasil terendah 65,48 . Hari pertama pada ruang pengelola terminal diwaktu pagi 73,76 $\mathrm{dB}(\mathrm{A})$ diakibatkan oleh banyak masuknya bus di terminal dan membunyikan klakson/sirine secara terus menerus, solusinya adalah diberikan tanda peringatan batas membunyikan klakson pada terminal. Tidak hanya ruang pengelola yang hasilnya tinggi, namun ruang pedagang untuk pagi dan sore yaitu 72,81dB(A) dan 71,59 $\mathrm{dB}(\mathrm{A})$ juga hasilnya tinggi, hasil tersebut diakibatkan oleh dekatnya tempat pemberhentian bus dan masuknya bus, mesin pada bus dinyalakan selama berhenti, solusinya adalah memasang tanda peringatan bila bus keadaan berhenti mesin bus di matikan. Hari kedua rata-rata pengukuran intensitas suara sebesar 67,42 $\mathrm{dB}(\mathrm{A})$ dengan hasil tertinggi yaitu 71,99 $\mathrm{dB}(\mathrm{A})$ dan terendah $64,18 \mathrm{~dB}(\mathrm{~A})$. Hasil tertinggi pada ruang tunggu yang disebabkan oleh banyaknya orang yang menawarkan jasa atau perjalanan, ditambah banyak kendaraan yang masuk dan membunyikan klakson atau sirine, solusinya tanda peringatan batas membunyikan klakson pada terminal.Hari ketiga ratarata pengukuran intensitas suara $63,68 \mathrm{~dB}(\mathrm{~A})$ dengan hasil tertinggi yaitu $71,39 \mathrm{~dB}(\mathrm{~A})$ dan terendah 55,24 $\mathrm{dB}(\mathrm{A})$.

Berdasarkan Peraturan Menteri Kesehatan No.718/Men/Kes/Per/XI/1987 tentang pembagian tingkat kebisingan khususnya di terminal yang diperbolehkan $70 \mathrm{~dB}(\mathrm{~A})$. Kebisingan yang terjadi pada 3 titik yaitu ruang pengelola terminal, ruang tunggu penumpang, dan ruang pedagang adalah kebisingan yang bersifat terputus-putus(intermittent), karena banyaknya lalu lintas bus seperti keluar masuknya bus di terminal. Rata-rata intensitas suara ruang pengelola, ruang tunggu penumpang, ruang pedagang dengan hasilnya 63,48 $\mathrm{dB}(\mathrm{A})$, memenuhi syarat.

Hasil wawancara pada pengunjung atau penumpang dari sembilan yang ditanya, tiga yang menjawab merasa terganggu oleh kebisingan aktifitas di terminal, untuk yang tidak merasa terganggu enam orang dikarenakan sudah terbiasa pada aktifitas di terminal.

Menurut J.F. Gabriel (1996,h.169) cahaya adalah jumlah penyinaran pada suatu bidang kerja yang diperlukan untuk melaksanakan kegiatan secara efektif, cahaya ada dua cahaya alami dan cahaya buatan. Pengukuran intensitas cahaya memperoleh hasil rata-rata yaitu 178,33 Lux, hari kedua memperoleh hasil intensitas cahaya untuk pagi dengan rata-rata 87,33 Lux, dan hari ketiga memperoleh hasil intensitas cahaya dengan rata-rata 245,66 Lux. Hasil rata-rata tertinggi disebabkan oleh berkontak langsung dengan sumber cahaya yang alami yaitu matahari, hasil rata-rata terendah disebabkan oleh kotornya penerangan dan sumber cahaya alami kurang masuk.

Menurut Menteri Kesehatan Republik Indonesia Nomor 1405/Menkes/SK/XI/2002 Tentang 
Persyaratan Kesehatan Lingkungan Kerja Perkantoran dan Industri standar tempat umum 100 Lux. Rata-rata pengukuran intensitas cahaya yaitu 170,44 Lux maka bila diandingkan standar tempat umum memenuhi syarat.

Hasil wawancara pada pengunjung atau penumpang dari sembilan yang ditanya ada dua yang menjawab bahwa diruangan kurang jelas untuk melakukan aktifitas, dan sisanya menjawab masih terlihat atau masih jelas untuk melakukan kegiatan atau aktifitas.

Menurut Diana Barsasella (2010,h.131) suhu adalah ukuran panas-dinginnya suatu benda, panasdinginnya suatu yang berkaitan dengan energi termis yang terkandung dalam benda tersebut. Pengukuran suhu pada hari pertama menghasilkan rata-rata 28,6 ${ }^{\circ} \mathrm{C}$ dengan hasil tertinggi yaitu $30{ }^{\circ} \mathrm{C}$ pada ruang pedagang dan hasil terendah $28^{\circ} \mathrm{C}$. Hasil tertinggi disebakan oleh aktifitas terminal. Pengukuran pada hari kedua menghasilkan rata-rata $31,1^{\circ} \mathrm{C}$ dengan hasil tertinggi yaitu $32{ }^{\circ} \mathrm{C}$ dan hasil terendah $30^{\circ} \mathrm{C}$. Hasil tertinggi disebabkan banyaknya penumpang yang datang seperti penumpang yang akan melakukan perjalanan, dan banyaknya pengunjung yang berkreasi di dalam terminal, naiknya suhu pada hari kedua karena hari tersebut hari libur. Solusinya menambah sirkulasi udara buatan seperti kipas angin. Pengukuran pada hari ketiga dengan rata-rata $28,5^{\circ} \mathrm{C}$ dengan hasil tertinggi $30^{\circ} \mathrm{C}$ dan untuk hasil terendah yaitu $28^{\circ} \mathrm{C}$.

Menurut Menteri Kesehatan Republik Indonesia Nomor 1405/Menkes/SK/XI/2002Tentang Persyaratan Kesehatan Lingkungan Kerja Perkantoran dan Industri standar suhu ruangan adalah $18-30{ }^{\circ} \mathrm{C}$, hasil rata-rata pengukuran hari pertama yaitu $28,6^{\circ} \mathrm{C}$ bila dibandingkan dengan standar maka memenuhi syarat. Pengukuran pada hari kedua menghasilkan rata-rata $31,1{ }^{\circ} \mathrm{C}$ bila dibandingkan dengan standar maka tidak memenuhi syarat, dan pengukuran hari ketiga dengan rata-rata $28,5{ }^{\circ} \mathrm{C}$ dibandingkan dengan standar maka hasilnya memenuhi syarat.

Hasil wawancara pada pengunjung atau penumpang dari sembilan orang ada 3 orang yang menjawab udara pada ruang tersebut sangat panas, ruangan yang dimaksud ruang tunggu penumpang. Hasil yang menjawab tidak panas ada enam orang.

Menurut Rahmat Kusnadi (2009,h.126) kelembaban adalah jumlah kandungan uap air yang ada dalam udara. Kandungan uap air di udara berubah-ubah bergantung pada suhu, makin tinggi suhu, makin banyak kandungan uap airnya. Pengukuran kelembaban pada hari pertama menghasilkan rata-rata $60,5 \%$, hasil tertinggi pada ruang tunggu penumpang pagi hari yaitu $70 \%$ pada ruang tunggu penumpang pagi hari dan terendah pada ruang pengelola $52 \%$. Hasil tertinggi disebabkan oleh banyaknya partikel uap air dan banyaknya aktifitas pada ruang tersebut, seperti banyaknya penumpang yang sedang menunggu bus yang akan digunakan. Pengukuran hari kedua mendapatkan ratarata hasil 51,3\% dengan hasil tertinggi $57 \%$ dan hasil terendah $48 \%$. Pengukuran hasil rata-rata pada hari ketiga adalah 52,8\% dengan hasil tertinggi $58 \%$ pada ruang pengelola sore hari dan hasil terendah 45 $\%$ pada ruang pedagang.

Menurut Menteri Kesehatan Republik Indonesia Nomor 1405/Menkes/SK/XI/2002Tentang Persyaratan Kesehatan Lingkungan Kerja Perkantoran dan Industri standar kelembaban pada ruangan adalah $40 \%-60 \%$, hasil rata-rata pengukuran hari pertama memperoleh $60,5 \%$ bila dibandingkan dengan standar maka tidak memenuhi syarat, hari kedua pengukuran dengan rata-rata $51,3 \%$ bila dibandingkan dengan standar maka memenuhi syarat, dan hari ketiga pengukuran dengan rata-rata 52,8\% bila dibandingkan dengan standar maka memenuhi syarat. Kenaikkan kelembaban pada hari pertama yaitu melebihi standar yang telah ditentukan. Hasil pengukuran kelembaban dengan rata-rata 54,8\% maka bila dibandingkan dengan standar yang berlaku memenuhi syarat.

Hasil wawancara pada sembilan orang tidak ada yang merasakan pusing karena aktifitas diterminal, karena rata-rata keberadaan pengunjung hanya sesaat dan tidak membutuhkan waktu lama untuk di terminal.

\section{IV.SIMPULAN}

Terminal Bus Bulupitu Purwokerto Kabupaten Banyumas termasuk dalam tipe A yang memiliki armada sebanyak 1852 unit dengan fungsi yang berbeda, kepadatan penumpang/pengunjung mencapai 5000 orang/hari.

Ruang pengelola terminal masuknya sumber cahaya alami sangat kurang. Ruang tunggu penumpang cahaya buatan yaitu lampu sudah redup, cat pada dinding sudah kusam, dan sangat lembab.

Ruang pedagang sangat terbuka, suara sangat ramai dan berdekatan dengan tempat parkir bus yang siap berangkat cahaya buatan sudah mulai kotor dan tidak berfungsi.

Hasil observasi dengan nilai 65,30 Terminal Bus Bulupitu Purwokerto Kabupaten Banyumas masuk kategori Baik.

Peneliti manyarankan untuk dilakukan penelitian selanjutnya tentang kenaikan jumlah penumpang/ pengunjung yang mengalami kebisingan, mata cepat pegal, kepanasan, dan pusing di terminal.

\section{UCAPAN TERIMA KASIH}

Ucapan terima kasih terutama ditunjukkan kepada UPT Terminal Bus Bulupitu Purwokerto Dishubkominfo Kabupaten Banyumas yang telah membantu pelaksanaan penelitian.

\section{DAFTAR PUSTAKA}

Departemen Kesehatan Republik Indonesia. (2014). Kesehatan Lingkungan. Jakarta : Depkes RI. 
Diana Barsasella. (2010). Fisika Untuk Mahasiswa Kesehatan. Jakarta : CV Trans Info Media.

Djamaluddin Ramlan, Meisye Marlyn Kuhu. (2013). Petunjuk Praktis Penulisan Penelitian Deskriptif. Purwokerto : UPT Percetakan dan Penerbitan Universitas Jenderal Soedirman Purwokerto.

H. J. Mukono. (2006). Prinsip Dasar Kesehatan Lingkungan. Surabaya : Universitas Airlangga Press.

J.F. Gabriel. (1996). Fisika Kedokteran. Jakarta : EGC.

Keputusan Menteri Republik Indonesia Nomor 288/Menkes/SK/III/2003 tentang Pedoman Penyehatan Sarana dan Bangunan Umum.

Menteri Kesehatan Republik Indonesia Nomor 1405/Menkes/SK/VI/2002 tentan Persyaratan Kesehatan Lingkungan Kerja Perkantoran dan Industri.
Peraturan Menteri Kesehatan Republik Indonesi Nomor 718/Men/Kes/Per/CI/1987 tentang Pembagian Kebisingan.

Ricki M. Mulia. (2005). Kesehatan Lingkungan. Yogyakarta : Graham Ilmu.

Soeripto M. (2008). Higiene Industri. Jakarta : Fakultas Kedokteran Universitas Indonesia.

Suharsini Arikunto. (1998). Prosedur Penelitian. Jakarta : Trineka Cipta.

Suma'mur. (2009). Higiene Perusahaan dan Kesehatan Kerja Edisi 2. Jakarta : CV. Haji Masagung.

Tri Cahyono. (2014). Pedoman Penulisan Proposal Penelitian dan Karya Tulis Ilmiah/ Skripsi. Purwokerto : Poltekkes Depkes Semarang Jurusan Kesehatan Lingkungan. 